\title{
Consumers' Trust in Greek Traditional Foods in the Post COVID-19 Era
}

\author{
Dimitris Skalkos $^{1, *(\mathbb{D}}$, Ioanna S. $\operatorname{Kosma}^{1} \mathbb{D}$, Areti Vasiliou ${ }^{1}$ and Raquel P. F. Guine ${ }^{2}(\mathbb{D})$ \\ 1 Laboratory of Food Chemistry, Department of Chemistry, University of Ioannina, 45110 Ioannina, Greece; \\ i.kosma@uoi.gr (I.S.K.); pch1162@uoi.gr (A.V.) \\ 2 CERNAS Research Centre, Polytechnic Institute of Viseu, 3504-510 Viseu, Portugal; raquelguine@esav.ipv.pt \\ * Correspondence: dskalkos@uoi.gr; Tel.: +30-2651008345
}

check for updates

Citation: Skalkos, D.; Kosma, I.S.;

Vasiliou, A.; Guine, R.P.F. Consumers' Trust in Greek Traditional Foods in the Post COVID-19 Era. Sustainability 2021, 13, 9975. https://doi.org/ $10.3390 /$ su13179975

Academic Editors: Richard James Volpe and Mario D'Amico

Received: 17 July 2021

Accepted: 1 September 2021

Published: 6 September 2021

Publisher's Note: MDPI stays neutral with regard to jurisdictional claims in published maps and institutional affiliations.

Copyright: (C) 2021 by the authors. Licensee MDPI, Basel, Switzerland. This article is an open access article distributed under the terms and conditions of the Creative Commons Attribution (CC BY) license (https:// creativecommons.org/licenses/by/ $4.0 /)$.

\begin{abstract}
We are entering a new, unprecedented global economic and social era following the COVID-19 pandemic, in which there will be opportunities and threats for the goods and services provided. Traditional foods (TFs) could have their chances in the new food chain which will be developed, as long as they become the food of choice for the consumers of the future. This paper investigates consumers' trust in Greek TFs, and northwest Greek TFs, in order to assess their potential consumption in the new economy. Trust was tested using the variables of safety, healthiness, sustainability, authenticity and taste, assessing consumers' confidence and satisfaction with the TFs, their raw materials, and the technologies used for their production. A self-response questionnaire survey was carried out in May and June 2021 on a sample of 548 participants through the Google platform. In order to analyze the data, basic descriptive statistical tools were used, combined with crosstabs and chi-square tests. The results show that the participants trust the Greek TFs because they "strongly agree" by an average of $20 \%$, and "agree" by an average of $50 \%$ that they are safe, healthy, sustainable, authentic and tasty. A similar pattern was recorded for the regional northwest Greek TFs as well. These results indicate that TFs could be the food of choice because they bear consumers' trust in the coming "new normality", where trust will be a major factor of choice for the purchase of goods and services.
\end{abstract}

Keywords: traditional foods; consumer trust; confidence and satisfaction; questionnaire survey; post COVID-19 period

\section{Introduction}

We are entering a new global economic and social era following the COVID-19 pandemic crisis. Philip Kotler predicts that the slowdown in global economic growth will lead to more unemployment, new consumer behavior, fewer businesses in place, and new measures for accessing the performance of economies [1]. Some countries are now preparing an annual measure of Gross Domestic Happiness (GDH) or Gross Domestic Well-Being (GDW) in order to measure the impact of economic growth in addition to Gross Domestic Product (GDP), which has been used exclusively so far [1]. Surveys conducted in 2020 investigated the food consumption behavior during the pandemic period, attempting to predict the post COVID-19 era as well. A US study in major metropolitan areas showed that patterns for major food groups seem to stay the same, but a large share indicated that they had been snacking more because of the beginning of the pandemic, which was offset by a sharp decline in fast food consumption [2]. A Swiss study revealed that consumers considered having more time to prepare meals themselves as being particularly important to achieving healthier food consumption [3]. An analysis of the datasets of food preparation recipes revealed differences in food consumption patterns in foods such as "Pulses/plants producing pulses", "Pancake/Tortilla/Oatcake", and "Soup/pottage", which increased by $300 \%, 280 \%$ and $100 \%$, respectively, during the pandemic [4]. A unique panel survey of representative households in Addis Ababa implied, at least indirectly, that in the aggregate 
food value chains have been resilient to the shock associated with the pandemic [5]. Our findings regarding the traditional foods of northwest Greece (TFs) also showed that the pandemic didn't interfere with people's consumption patterns and preferences [6].

\section{Literature Review}

TFs are a major economic resource, as the food of choice for many cultures and regions across the world, contributing to their sense of identity, pride and prosperity [7]. They represent key elements of dietary patterns in different countries, and thus they are important for the accurate calculation of the dietary intake by the population [8]. Over the last decade, consumers have shown increased acceptance for TFs, especially in Europe $[9,10]$, which may generate increased growth after the pandemic period [11]. The European Union, since 1992, has had specific rules defining the status under which TFs are designated in three categories [12]: Protected Designation of Origin (PDO), Protected Geographical Indication (PGI), and Traditionally Specific Guaranteed (TSG). These regulations were amended to 509/06 and 510/06, respectively, shortly after the Euro FIR (Food Information Resource) London Congress [13,14]. Currently, EU regulation 1151/12 helps producers of TFs to communicate the products' characteristics and farming attributes to buyers and consumers by establishing voluntary quality schemes [15]. The definition of the term 'traditional' in the above document means proven usage on the domestic market for a period that allows transmission between generations, with this period being at least 30 years.

Greece has incorporated the provisions of the Regulation into the national Legislation with Ministerial Decree (3321/145849) issued by the Hellenic Ministry of Food and Agricultural Development since 2006 [16]. Furthermore, a system of checks at all of the stages of production, processing and distribution of geographical indications and traditional specialties guaranteed was established, and is being implemented by the Hellenic Agricultural Organization, Demetra (AGROCERT). All of the registered traditional Greek foods are shown by their different types in Table 1.

Table 1. Distribution of the Greek recognized foods between the different categories.

\begin{tabular}{cccc}
\hline Type of Food Products & PDOs & PGIs & TSGs \\
\hline Wine & 33 & 116 & \\
Olive oil & 21 & & \\
Meat & 2 & 1 & \\
Cheese & 22 & & 1 \\
Foods of animal origin & 2 & 21 & 1 \\
Fish & 1 & & \\
Fruits \& vegetables & 29 & 138 & 1 \\
Others & 6 &
\end{tabular}

Greece has registered 116 PDO products out of a total of 661 in eAmbrosia, the EU Geographical Indication Register [17]. The majority of the Greek PDO foods (33) belong to wines, and 29 belong to the class of fruit and vegetables, fresh or processed. There are also 138 Greek PGI products out of the 881 in the register. In the class of "others" belong the Chios' masticha, Chios' masticha oil, Chios' masticha gum, the safran of Kozani, the Kretan rusk and the melekouni dessert of Rodos. Surprisingly, there is only one Greek TSG food in the register, despite the wide variety of Greek traditional products and food recipes.

The TFs of northwest Greece (namely the region of Epirus) comprise a significant portion of the overall Greek TFs. It is a region with a long history of local traditional food products, such as the traditional green pies used for the feeding of its residents. Livestocksheep and goats-have been developed as the primary self-employment by the regional farmers for centuries, producing milk, which has been used for cheese. Besides this, the farmers also made other dairy TF products, as well as wine, pasta, honey, oil, herbs or 
legumes, among others. Selected regional TFs, mainly the PDO cheeses and wines, are exported throughout Europe, thus promoting the regional brand name.

As has been reported for other countries [18], Greek cuisine can be represented by a triangle of influences and connections: food, culture and history. These relationships explain the link between food and the culture of the local community in a region, and this has resulted in the culinary tradition. The longevity associated with the Mediterranean Diet could be partly attributed to Mediterranean traditional foods, which this diet incorporates, including Greek traditional foods [19]. The analysis of several traditional Greek foods indicated that they may contribute to the apparent health benefits of the Greek version of the Mediterranean diet [20-22]. The traditional Greek diet favors plant foods with antioxidant potential, which are considered to provide protection from coronary heart disease and cancer, providing a high antioxidant content to the Greek Mediterranean $\operatorname{diet}[23-25]$.

In the post COVID-19 era, a major issue for the customer will be the trust in the products and services he will choose to buy. Food will be included in his daily agenda of preferences and choices. Consumer trust in food has become a major concern in the debate around food policy in recent years [26-28]. Trust was an important predictor of the acceptance of water recycling, both directly and indirectly through the reduction of risk perceptions [29], while trust in the food industry was important in influencing the acceptance of functional foods and foods affected by nanotechnology [30]. Lobb et al. showed significant interactions between trust, risk perceptions, and attitudes in UK consumers decisions to purchase chicken [31]. Janssen and Hamm showed the importance of trust in the acceptance of certain types of (unfamiliar and more familiar) organic food labels [32]. Jonge et al.'s research showed that consumer trust in the safety of the food supply was mainly related to specific trust dimensions that were different for different products in the food chain [33]. The lack of trust and the ensuing lack of confidence is not only a problem for the food chain actors trying to develop and market food products in the post COVID-19 era but also a barrier for attempts to enact transformations of the food system that are widely believed to be necessary. Recent research illustrated the need for behavioral change by consumers $[34,35]$, most notably towards more sustainable and healthier food choices [36].

The aim of the present work was to assess the factors associated with consumers' trust in Greek TFs in view of the post COVID-19 era in order to predict their future prospect, growth and development in the new rising economy. In order to accomplish this objective, following the existing literature on the parameters of food trust [37-42], the current study examines the following five determinants of consumers' trust in Greek TFs in the post COVID-19 period:

(I) Consumers' trust in the safety of the Greek TFs. This involves characteristics such as hygiene, freshness, traceability, transparency, controlled processes and additives, allergen labels and certified quality.

(II) Consumers' trust in the healthiness of the Greek TFs. This involves characteristics such as being natural, being organic, having fewer chemicals, being less processed, having fewer additives, being good for you, having low sugar/salt, and being vegetarian/vegan.

(III) Consumers' trust in the sustainability of the Greek TFs This involves characteristics such as being local, seasonal and low carbon; fair production; animal welfare; involving less meat and less packaging; being recyclable and organic; and having no chemicals.

(IV) Consumers' trust in the authenticity of the Greek TFs. This involves characteristics such as being genuine, local and nostalgic; having natural ingredients; being unprocessed; having few additives; being non-uniform; and having a certified provenance and traceability. 
(V) Consumers' trust in the taste of the Greek TFs. This involves characteristics such as freshness, quality, intense flavor, sensory characteristics, the individual pleasure of eating, and valuing substance over appearance.

(VI) Consumers' trust in the Northwest Greek TFs (Epirus' region). This involves the characteristics of safety, healthiness, sustainability, authenticity, and taste mentioned in $\mathrm{I}-\mathrm{V}$ above.

The consumers' trust in the technologies and raw materials used for food production was also evaluated in our study. In order to understand better the customers' perception, not only their confidence in each item of trust was evaluated (for the TFs and their technologies) but also their satisfaction with the same items.

\section{Materials and Methods}

\subsection{Data Collection and Sample Characterization}

The data collection was based on a questionnaire prepared to investigate the motivations that influence consumers' trust concerning Greek TFs, including the TFs of the Epirus region. The questionnaire was built up in seven parts. Each question was created in such a way that it could provide the best possible information for each section. The parts were built up using a similar previous study [43]. The first part included questions about the social-demographic characteristics of the respondents, specifically gender, age, level of education, civil state job situation, and permanent residency in different parts of Greece. The second part consisted of five questions designed to assess the confidence in the safety of the TFs, their production process and their raw materials, which lead the participants to purchasing in the post COVID era. The third part included five questions focused on the participant's confidence in the healthiness of the TFs, which motivates their purchase. In the fourth part, issues concerning the participants' confidence in the sustainability of TFs were assessed through five questions. The fifth part included five questions that approached the buying behavior of the participants in relation to their confidence in the authenticity of TFs. In the sixth part, using five questions, the participants' preference of the TFs regarding their confidence in the taste of the TFs was assessed. Finally, in the seventh part, using ten questions, the participants were asked to respond and provide information on their trust in the northwest Greek TFs, which can direct their preference to these foods. Issues such as safety, healthiness, sustainability, authenticity and taste were taken into consideration. In order to guarantee the quality of the data obtained through the application of the questionnaire, this was pretested with 30 respondents. This phase was pivotal to ensure that the questions were clear and understandable, such that the respondents could answer them easily. The research was carried out using electronic questionnaires, as it was easier to distribute and collect during the semi-lockdown period. The distribution method chosen was by e-mail, as was similarly performed in papers investigating consumer behaviors [44-46]. A snowball method was used in order to obtain a large number of participants [47]. The sample of the population is very well distributed, because it included a wide range of ages and civil states, etc., and the participants were familiar with the new technologies. A higher rate for female respondents was recorded, at $57.9 \%$; this is similar to the observations of other papers as well [48-51], leading to the conclusion that women respond more willingly to food-related surveys because they are primarily involved in the household organization, consisting of people who are familiar with the concept of TF, and therefore could provide reliable answers (in order to accurately describe their choice to buy these foods). The research questionnaire was created through the Google platform and the Google Forms function due to the ability to directly export the results to an Excel sheet for further processing. The geographical context for the present study was all of the Greek territory, divided into five parts: north-west-central-south and the islands, because the country includes many of them in the Aegean and the Ionian seas. The sample included students, among others, and through them the questionnaire was made available to their families, friends and acquaintances. The respondents received e-mails explaining the purpose of the research and the importance of their participation, 
while there was an attached link that led to the electronic form of the questionnaire. The responses were anonymous, and no personal information was collected or correlated with any of the responses in order to ensure the protection of the participants.

The survey took place during the period May-June 2021, and consisted of the information shown in Table 2.

Table 2. Sociodemographic characterization of the sample.

\begin{tabular}{|c|c|c|}
\hline Variable & Groups & $(\%)$ \\
\hline \multirow[b]{2}{*}{ Gender } & Male & 42.1 \\
\hline & Female & 57.9 \\
\hline \multirow{5}{*}{ Age } & $18-25$ & 18.3 \\
\hline & $26-35$ & 25.8 \\
\hline & $36-45$ & 17.8 \\
\hline & $46-55$ & 25.6 \\
\hline & $56+$ & 12.5 \\
\hline \multirow{4}{*}{ Level of education } & None/Primary school & 0.6 \\
\hline & Secondary school & 0.4 \\
\hline & High school & 14.5 \\
\hline & University & 84.6 \\
\hline \multirow{3}{*}{ Civil state } & Single & 44.3 \\
\hline & Married & 49.6 \\
\hline & Divorced & 6.1 \\
\hline \multirow{3}{*}{ Job situation } & Employed & 74.6 \\
\hline & Unemployed & 8.2 \\
\hline & Student & 17.3 \\
\hline \multirow{5}{*}{ Permanent resident in Greece } & $\begin{array}{l}\text { NORTH GREECE (regions of } \\
\text { Macedonia-Thrace) }\end{array}$ & 23.8 \\
\hline & $\begin{array}{l}\text { WEST GREECE (region of } \\
\text { Epirus-Etoloakarnania prefecture) }\end{array}$ & 41.3 \\
\hline & $\begin{array}{l}\text { Epirus-Etoloakarnania prefecture) } \\
\text { CENTRAL GREECE (including Athens) }\end{array}$ & 24.7 \\
\hline & SOUTH GREECE (region of Peloponnese) & 2.6 \\
\hline & ISLANDS (Ionian and Aegean) & 7.7 \\
\hline
\end{tabular}

Of the 548 participants, $42.1 \%$ were male and $57.9 \%$ female. Regarding the spacial distribution, $41.3 \%$ were permanent residents of west Greece, $24.7 \%$ of were residents central Greece (including the capital, Athens), 23.8\% were residents of north Greece, $7.7 \%$ were residents of the Greek islands, and $2.6 \%$ were residents of south Greece, leading to a wide geographic distribution. The majority of the participants were aged 26-35, 46-55, $18-25$, and $36-45$ years $(25.8 \%, 25.6 \%, 18.3 \%$, and $17.8 \%$ respectively), while the other age group, $56+$, was the least represented (12.5\%). Regarding the level of education, most of the participants had higher education (university, $84.6 \%$ ), and only $1 \%$ had only completed primary or secondary school, while the employment status category was dominated by employed $(74.6 \%)$ participants. Regarding the civil state of the participants, $49.6 \%$ were married, $44.3 \%$ single, and $6.1 \%$ were divorced.

\subsection{Data Analysis}

The exploratory analysis of the data was achieved through basic statistical tools. The survey was prepared in Greek, and was divided into six parts, as detailed above:

Part I. Sociodemographic data (see Table 1).

Part II. Consumers' trust in the safety of the Greek TFs.

Part III. Consumers' trust in the healthiness of the Greek TFs.

Part IV. Consumers' trust in the sustainability of the Greek TFs.

Part V. Consumers' trust in the authenticity of the Greek TFs.

Part VI. Consumers' trust in the taste of the Greek TFs.

Part VII. Consumers' trust in the northwest Greek TFs. 
The raw materials and the technologies used for the traditional foods were considered seperately, and therefore they were assessed separately. Furthermore, the consumers' confidence was considered separately from the satisfaction for the trust in the TFs and in the technologies used to produce them.

The sociodemographic characteristics were collected in the first part of the questionnaire. In order to measure the respondents' opinion about a set of statements related to TFs, a 5-point Likert scale, ranging from $1=$ strongly disagree to $5=$ strongly agree, was used [52].

The statistical processing of the data was performed using IBM SPSS Statistics for Windows (Version 25.0, IBM Corp., Armonk, NY, USA) on the data before proceeding with the other statistical tests. The data obtained from the Likert scale were considered as ordinal values.

Nonparametric tests were used. The nonparametric testing was performed in order to test the distribution of the variables of each group and response based on the hypothesized equal proportions for each variable. The Chi-Square Independence Test was used to determine whether there is an association between the variables. Cramer's V coefficient was used to analyze the strength of the significant relations found between some of the variables in the study. This coefficient ranged from 0 to 1 , and can be interpreted as follows: $\mathrm{V} \approx 0.1$, the association is considered weak; $\mathrm{V} \approx 0.3$, the association is moderate; and $\mathrm{V} \approx 0.5$ or over, the association is strong. Sociodemographic characteristics were considered as predictor variables that could affect the other responses of the questionnaire. In all of the tests performed, the level of significance considered was $5 \%(p<0.05)$.

\section{Results}

In the results presented in the tables below, the percentages of strongly disagree (1) and disagree (2) were less than $10 \%$ in all of the questions of the study. Answer number 3 corresponds to "neither disagree nor agree" for all of the questions used in the study. Table 3 presents the participants' perceptions of the safety of Greek TFs, their raw materials, and the technologies used to produce them in the post COVID-19 period. The results show that the majority of the participants agree that they will be safe (for the TFs by $51.9 \%$ for confidence and $56.9 \%$ for satisfaction; for the raw materials by $55.4 \%$; and for the technologies used by $55.1 \%$ for confidence and $57.2 \%$ for satisfaction). A significant part, more than $20 \%$, strongly agree on the safety of the products (for TFs by $29.1 \%$ for confidence and $24.4 \%$ for satisfaction, for raw materials by $23 \%$, and for the technologies used by $20 \%$ for confidence and $19.3 \%$ for satisfaction)....

Table 3. Participants' confidence in the safety of the Greek TFs (Scale from $1=$ strongly disagree to $5=$ strongly agree).

\begin{tabular}{|c|c|c|c|c|c|}
\hline \multirow{2}{*}{ Questions } & \multicolumn{5}{|c|}{ Answers According to Scale Points (\%) } \\
\hline & 1 & 2 & 3 & 4 & 5 \\
\hline 1. I am confident that the Greek TFs will be safe in the post COVID-19 era & 0.5 & 2.4 & 16.1 & 51.9 & 29.1 \\
\hline 2. I will be satisfied with the safety of the Greek TFs in the post COVID-19 era & 0.4 & 2.6 & 15.8 & 56.9 & 24.4 \\
\hline $\begin{array}{l}\text { 3. The Greek TFs will be produced with safe raw materials in the post } \\
\text { COVID-19 era }\end{array}$ & 0.4 & 2.4 & 18.8 & 55.4 & 23.0 \\
\hline $\begin{array}{l}\text { 4. I am confident that the food technologies of the Greek TFs will be safe in the post } \\
\text { COVID-19 era }\end{array}$ & 0.4 & 3.1 & 21.4 & 55.1 & 20.0 \\
\hline $\begin{array}{l}\text { 5. I will be satisfied with the safety of the food technologies of the Greek TFs in the } \\
\text { post COVID-19 era }\end{array}$ & 0.4 & 2.2 & 20.9 & 57.2 & 19.3 \\
\hline
\end{tabular}


The chi-square test, presented in Table 6, showed that there were significant differences between the perceptions for TFs' safety in terms of:

1. Confidence in the safety of the Greek TFs: only between age $\left(x^{2}=32.714, p=0.008\right)$ and level of education $\left(x^{2}=75.835, p=0.000\right)$.

2. Satisfaction with the safety of the Greek TFs: between age $\left(x^{2}=33.380, p=0.007\right)$, level of education $\left(x^{2}=104.816, p=0.000\right)$, civil state $\left(x^{2}=18.329, p=0.019\right)$ and job situation $\left(x^{2}=16.419, p=0.037\right)$.

3. The safety of the raw materials used: between gender $\left(x^{2}=14.567, p=0.006\right)$, level of education $\left(x^{2}=365.786, p=0.000\right)$ and residency $\left(x^{2}=34.132, p=0.005\right)$

4. Confidence in the safety of the technologies used: between age $\left(x^{2}=30.135, p=0.017\right)$, level of education $\left(x^{2}=102.641, p=0.000\right)$ and job situation $\left(x^{2}=24.197, p=0.002\right)$.

5. Satisfaction with the safety of the technologies used: between age $\left(x^{2}=27.170\right.$, $p=0.040)$, level of education $\left(x^{2}=106.212, p=0.000\right)$, job situation $\left(x^{2}=26.035\right.$, $p=0.001)$ and residency $\left(x^{2}=29.897, p=0.019\right)$.

Table 4 presents the participants' perceptions of the healthiness of the Greek TFs, their raw materials, and their technologies in the new era after COVID-19. The results show that more than $55 \%$ of the participants agree that they are healthy (for the TFs themselves, by $55.4 \%$ for confidence, by $57.2 \%$ for satisfaction, for the raw materials by $53.8 \%$, and for the technologies used by $56.4 \%$ for confidence and $56.3 \%$ for satisfaction). A portion around $18 \%$ strongly agree that they are healthy (for TFs by $20.8 \%$ for confidence and $20.7 \%$ for satisfaction, for raw materials by $18.7 \%$, and for the technologies used by $17.1 \%$ for confidence, and $16.3 \%$ for satisfaction).

Table 4. Participants' confidence in the healthiness of the Greek TFs (Scale from $1=$ strongly disagree to $5=$ strongly agree).

\begin{tabular}{|c|c|c|c|c|c|}
\hline \multirow{2}{*}{ Questions } & \multicolumn{5}{|c|}{ Answers According to Scale Points (\%) } \\
\hline & 1 & 2 & 3 & 4 & 5 \\
\hline 1. I am confident that the Greek TFs will be healthy in the post COVID-19 era & 0.2 & 3.5 & 20.1 & 55.4 & 20.8 \\
\hline 2. I will be satisfied with the healthiness of the Greek TFs in the post COVID-19 era & 0.6 & 2.4 & 19.1 & 57.2 & 20.7 \\
\hline $\begin{array}{l}\text { 3. The Greek TFs will be produced with healthy raw materials in the post } \\
\text { COVID-19 era }\end{array}$ & 0.9 & 3.1 & 23.5 & 53.8 & 18.7 \\
\hline $\begin{array}{l}\text { 4. I am confident that the food technologies of the Greek TFs will result in healthy } \\
\text { food products in the post COVID-19 era }\end{array}$ & 0.4 & 3.3 & 22.8 & 56.4 & 17.1 \\
\hline $\begin{array}{l}\text { 5. I will be satisfied with how in the post COVID- } 19 \text { era the food technologies of the } \\
\text { Greek TFs will result in healthy food products }\end{array}$ & 0.2 & 2.9 & 24.2 & 56.3 & 16.3 \\
\hline
\end{tabular}

The results of the chi-square test, presented in Table 6, showed that there were significant differences between the perceptions for TFs' healthiness in terms of the level of education and job situation only:

1. Confidence in the healthiness of the Greek TFs: only between the level of education $\left(x^{2}=184.489, p=0.000\right)$ and job situation $\left(x^{2}=26.619, p=0.001\right)$.

2. Satisfaction with the healthiness of the Greek TFs: only between the level of education $\left(x^{2}=62.647, p=0.000\right)$ and job situation $\left(x^{2}=17.180, p=0.028\right)$.

3. Healthiness of the raw materials used: only between the level of education $\left(x^{2}=47.320\right.$, $p=0.000)$.

4. Confidence in the healthiness of the technologies used: only between the level of education $\left(x^{2}=103.465, p=0.000\right)$.

5. Satisfaction with the healthiness of the technologies used: only between the level of education $\left(x^{2}=22.337, p=0.034\right)$.

Table 5 presents the participants' perceptions of the sustainability of the Greek TFs, their raw materials, and their technologies used after the pandemic. The results show that an average of $50 \%$ of the participants agree that they are sustainable (for the TFs by $49.4 \%$ for confidence and $49.2 \%$ for satisfaction, for the raw materials by $51.9 \%$, and for the 
technologies used by $49.0 \%$ for confidence and $52.0 \%$ for satisfaction). A low percentage strongly agree that they are sustainable products (for TFs by $16.9 \%$ for confidence and $14.4 \%$ for satisfaction, for the raw materials by $13.5 \%$, and for the technologies used by $12.2 \%$ for confidence and $12.4 \%$ for satisfaction).

Table 5. Participants' confidence in the sustainability of Greek TFs (Scale from $1=$ strongly disagree to $5=$ strongly agree).

\begin{tabular}{|c|c|c|c|c|c|}
\hline \multirow{2}{*}{ Questions } & \multicolumn{5}{|c|}{ Answers According to Scale Points (\%) } \\
\hline & 1 & 2 & 3 & 4 & 5 \\
\hline $\begin{array}{l}\text { 1. I am confident that the Greek TFs will be produced in a sustainable way in the } \\
\text { post COVID-19 era (i.e., environmentally friendly, resource efficient, } \\
\text { ethically responsible) }\end{array}$ & 1.1 & 7.5 & 25.1 & 49.4 & 16.9 \\
\hline $\begin{array}{l}\text { 2. I will be satisfied with the sustainability of the Greek TFs in the post COVID-19 } \\
\text { era (i.e., they will be produced in a way that will be environmentally friendly, } \\
\text { resource efficient, ethically responsible) }\end{array}$ & 1.7 & 6.3 & 28.5 & 49.2 & 14.4 \\
\hline $\begin{array}{l}\text { 3. The Greek TFs will be produced with raw materials produced in a sustainable } \\
\text { way in the post COVID-19 era (i.e., environmentally friendly, resource efficient, } \\
\text { ethically responsible) }\end{array}$ & 1.8 & 5.4 & 27.4 & 51.9 & 13.5 \\
\hline $\begin{array}{l}\text { 4. I am confident that the food technologies of the Greek TFs will be sustainable in } \\
\text { the post COVID-19 era (i.e., environmentally friendly, resource efficient, } \\
\text { ethically responsible) }\end{array}$ & 1.5 & 7.4 & 30.0 & 49.0 & 12.2 \\
\hline $\begin{array}{l}\text { 5. I will be satisfied with the sustainability of the food technologies of the Greek } \\
\text { TFs in the post COVID-19 era (i.e., they will be produced in a way that will be } \\
\text { environmentally friendly, resource efficient, ethically responsible) }\end{array}$ & 0.9 & 7.6 & 27.1 & 52.0 & 12.4 \\
\hline
\end{tabular}

The results of the chi-square test, presented in Table 6, showed that there were significant differences between the perceptions of TFs' sustainability in terms of:

1. Confidence in the sustainability of the Greek TFs: only between civil state $\left(x^{2}=22.102\right.$, $p=0.005)$.

2. Satisfaction with the sustainability of the Greek TFs: only between the level of education $\left(x^{2}=24.912, p=0.015\right)$ and job situation $\left(x^{2}=18.179, p=0.020\right)$.

3. The sustainability of the raw materials used: between level of education $\left(x^{2}=28.650\right.$, $p=0.004)$, civil state $\left(x^{2}=19.215, p=0.014\right)$ and job situation $\left(x^{2}=22.237, p=0.004\right)$.

4. Confidence in the sustainability of the technologies used: only between level of education $\left(x^{2}=30.864, p=0.002\right)$ and job situation $\left(x^{2}=28.307, p=0.000\right)$.

5. Satisfaction with the sustainability of the technologies used: between age $\left(x^{2}=32.331\right.$, $p=0.009)$, civil state $\left(x^{2}=23.388 p=0.003\right)$ and job situation $\left(x^{2}=16.995, p=0.030\right)$.

Table 7 presents the participants' perceptions of the authenticity of the Greek TFs, their raw materials, and the technologies used in the post COVID-19 era. The results show that an average of $50 \%$ of the participants agree that they are authentic products (for the TFs by $48.7 \%$ for confidence and $50.8 \%$ for satisfaction, for the raw materials by $48.6 \%$, and for the technologies used by $49.0 \%$ for confidence and $51.3 \%$ for satisfaction). A low percentage of less than 15\% strongly agree that they are authentic products (for TFs by $14.3 \%$ for confidence and $14.2 \%$ for satisfaction, for the raw materials by $13.0 \%$, and for the technologies used by $12.4 \%$ for confidence and $12.4 \%$ for satisfaction). 
Table 6. Associations between the variables: (A) the safety, (B) the healthiness and (C) the sustainability of Greek TFs, and the sociodemographic variables.

\begin{tabular}{|c|c|c|c|c|c|c|c|c|c|c|c|c|c|c|c|c|c|c|}
\hline & \multicolumn{3}{|c|}{ Gender } & \multicolumn{3}{|c|}{ Age } & \multicolumn{3}{|c|}{ Level of Education } & \multicolumn{3}{|c|}{ Civil State } & \multicolumn{3}{|c|}{ Job Situation } & \multicolumn{3}{|c|}{ Residency } \\
\hline & $\mathrm{x}^{2 *}$ & $p^{* *}$ & $\mathrm{~V}^{* * *}$ & $x^{2}$ & $p$ & $\mathrm{v}$ & $x^{2}$ & $p$ & $\mathrm{v}$ & $x^{2}$ & $p$ & $\mathrm{v}$ & $x^{2}$ & $p$ & $\mathrm{v}$ & $x^{2}$ & $p$ & $\mathrm{v}$ \\
\hline \multicolumn{19}{|l|}{ A. Safety of the Greek TFs } \\
\hline 1. I am confident that the Greek TFs will be safe in the post COVID-19 era & & & & 32.714 & 0.008 & 0.122 & 75.835 & 0.000 & 0.215 & & & & & & & & & \\
\hline $\begin{array}{l}\text { 2. I will be satisfied with the safety of the Greek TFs in the post } \\
\text { COVID-19 era }\end{array}$ & & & & 33.380 & 0.007 & 0.124 & 104.816 & 0.000 & 0.254 & 18.329 & 0.019 & 0.130 & 16.419 & 0.037 & 0.124 & & & \\
\hline $\begin{array}{l}\text { 3. The Greek TFs will be produced with safe raw materials in the post } \\
\text { COVID-19 era }\end{array}$ & 14.567 & 0.006 & 0.164 & & & & 365.786 & 0.000 & 0.473 & & & & & & & 34.132 & 0.005 & 0.125 \\
\hline $\begin{array}{l}\text { 4. I am confident that the food technologies of the Greek TFs will be safe in } \\
\text { the post COVID-19 era }\end{array}$ & & & & 30.135 & 0.017 & 0.118 & 102.641 & 0.000 & 0.251 & & & & 24.197 & 0.002 & 0.150 & & & \\
\hline $\begin{array}{l}\text { 5. I will be satisfied with the safety of the food technologies of the Greek } \\
\text { TFs in the post COVID-19 era }\end{array}$ & & & & 27.170 & 0.040 & 0.112 & 106.212 & 0.000 & 0.255 & & & & 26.035 & 0.001 & 0.156 & 29.897 & 0.019 & 0.117 \\
\hline \multicolumn{19}{|l|}{ B. Healthiness of the Greek TFs } \\
\hline $\begin{array}{l}\text { 1. I am confident that the Greek TFs will be healthy in the post } \\
\text { COVID-19 era }\end{array}$ & & & & & & & 184.469 & 0.000 & 0.336 & & & & 26.619 & 0.001 & 0.157 & & & \\
\hline $\begin{array}{l}\text { 2. I will be satisfied with the healthiness of the Greek TFs in the post } \\
\text { COVID-19 era }\end{array}$ & & & & & & & 62.647 & 0.000 & 0.196 & & & & 17.180 & 0.028 & 0.126 & & & \\
\hline $\begin{array}{l}\text { 3. The Greek TFs will be produced with healthy raw materials in the post } \\
\text { COVID- } 19 \text { era }\end{array}$ & & & & & & & 47.320 & 0.000 & 0.170 & & & & & & & & & \\
\hline $\begin{array}{l}\text { 4. I a confident that the food technologies of the Greek TFs will result in } \\
\text { healthy food products in the post COVID-19 era }\end{array}$ & & & & & & & 103.465 & 0.000 & 0.252 & & & & & & & & & \\
\hline $\begin{array}{l}\text { 5. I will be satisfied with how in the post COVID-19 era } \\
\text { the food technologies of the Greek TFs will result in healthy food products }\end{array}$ & & & & & & & 22.337 & 0.034 & 0.117 & & & & & & & & & \\
\hline \multicolumn{19}{|l|}{ C. Sustainability of the Greek TFs } \\
\hline $\begin{array}{l}\text { 1. I am confident that the Greek TFs will be produced in a sustainable way } \\
\text { in the post COVID-19 era (i.e., environmentally friendly, resource efficient, } \\
\text { ethically responsible) } \\
\text { 2. I will be satisfied with the sustainability of the Greek TFs in the post }\end{array}$ & & & & & & & & & & 22.102 & 0.005 & 0.143 & & & & & & \\
\hline $\begin{array}{l}\text { sustainable way in the post COVID-19 era (i.e., environmentally friendly, } \\
\text { resource efficient, ethically responsible) } \\
\text { 4. I am confident that the food technologies of the Greek TFs will be }\end{array}$ & & & & & & & 28.650 & 0.004 & 0.133 & 19.215 & 0.014 & 0.134 & 22.237 & 0.004 & 0.144 & & & \\
\hline $\begin{array}{l}\text { 4. I am confident that the food technologies of the Greek TFs will be } \\
\text { sustainable in the post COVID-19 era (i.e., environmentally friendly, } \\
\text { resource efficient, ethically responsible) } \\
\text { 5. I will be satisfied with the sustainability of the food technologies of the }\end{array}$ & & & & & & & 30.864 & 0.002 & 0.138 & & & & 28.307 & 0.000 & 0.162 & & & \\
\hline $\begin{array}{l}\text { Greek TFs in the post COVID-19 era (i.e., they will be produced in a way } \\
\text { that will be environmentally friendly, resource efficient, } \\
\text { ethically responsible) }\end{array}$ & & & & 32.331 & 0.009 & 0.122 & & & & 23.388 & 0.003 & 0.147 & 16.995 & 0.030 & 0.126 & & & \\
\hline
\end{tabular}


Table 7. Participants' confidence in the authenticity of the Greek TFs (Scale from $1=$ strongly disagree to $5=$ strongly agree).

\begin{tabular}{|c|c|c|c|c|c|}
\hline \multirow{2}{*}{ Questions } & \multicolumn{5}{|c|}{ Answers According to Scale Points (\%) } \\
\hline & 1 & 2 & 3 & 4 & 5 \\
\hline $\begin{array}{l}\text { 1. I am confident that the Greek TFs will be authentic in the post COVID-19 era } \\
\text { (real, honest, genuine, not fake or artificial) }\end{array}$ & 0.4 & 8.2 & 28.4 & 48.7 & 14.3 \\
\hline $\begin{array}{l}\text { 2. I will be satisfied with the authenticity of the Greek TFs in the post COVID-19 } \\
\text { era (they will be real, honest, genuine, not fake or artificial) }\end{array}$ & 0.6 & 6.1 & 28.4 & 50.8 & 14.2 \\
\hline $\begin{array}{l}\text { 3. The Greek TFs will be produced with authentic raw materials in the post } \\
\text { COVID-19 era (real, honest, genuine, not fake or artificial) }\end{array}$ & 0.7 & 6.8 & 30.8 & 48.6 & 13.0 \\
\hline $\begin{array}{l}\text { 4. I am confident that the food technologies of the Greek TFs will be authentic in } \\
\text { the post COVID-19 era (real, honest, genuine, not fake or artificial) }\end{array}$ & 0.4 & 6.7 & 31.5 & 49.0 & 12.4 \\
\hline $\begin{array}{l}\text { 5. I will be satisfied with the authenticity of the food technologies of the Greek TFs } \\
\text { in the post COVID-19 era (they will be real, honest, genuine, not fake or artificial) }\end{array}$ & 0.9 & 5.7 & 29.6 & 51.3 & 12.4 \\
\hline
\end{tabular}

The results of the chi-square test, presented in Table 10, showed that there were significant differences between perceptions for TFs' authenticity in terms of:

1. Confidence for the authenticity of the Greek TFs: only between the level of education $\left(x^{2}=94.729, p=0.000\right)$ and job situation $\left(x^{2}=19.508, p=0.012\right)$.

2. Satisfaction with the authenticity of the Greek TFs: between gender $\left(x^{2}=9.741\right.$, $p=0.045)$, age $\left(x^{2}=27.304 p=0.038\right)$ and level of education $\left(x^{2}=69.304, p=0.000\right)$.

3. Authenticity of the raw materials used: only between gender $\left(x^{2}=10.551, p=0.032\right)$.

4. Confidence in the authenticity of the technologies used: between gender $\left(x^{2}=10.758\right.$, $p=0.029)$, age $\left(x^{2}=32.726, p=0.008\right)$ and job situation $\left(x^{2}=16.787, p=0.032\right)$.

5. Satisfaction with the authenticity of the technologies used: only between the level of education $\left(x^{2}=57.836, p=0.000\right)$.

Table 8 presents the participants' perception of the taste of the Greek TFs, their raw materials, and their technologies used in the new economy following the pandemic. The results show that a significant percentage-more than $55 \%$ - of the participants agree that they are tasty products (for the TFs by $57.4 \%$ for confidence and $57.3 \%$ for satisfaction, for the raw materials by $57.2 \%$, and for the technologies used by $56.0 \%$ for confidence and $55.8 \%$ for satisfaction). A relatively high percentage-more than $20 \%$-strongly agree that they are tasty products (for TFs by $25.4 \%$ for confidence and $24.8 \%$ for satisfaction, for the raw materials by $21.9 \%$, and for the technologies used by $21.1 \%$ for confidence and $20.4 \%$ for satisfaction).

Table 8. Participants' confidence in the taste of the Greek TFs (scale from $1=$ strongly disagree to $5=$ strongly agree).

\begin{tabular}{|c|c|c|c|c|c|}
\hline \multirow{2}{*}{ Questions } & \multicolumn{5}{|c|}{ Answers According to Scale Points (\%) } \\
\hline & 1 & 2 & 3 & 4 & 5 \\
\hline 1. I am confident that the Greek TFs will be tasty in the post COVID-19 era & 0.2 & 0.9 & 16.2 & 57.4 & 25.4 \\
\hline 2. I will be satisfied with the taste of the Greek TFs in the post COVID-19 era & & 0.9 & 17.0 & 57.3 & 24.8 \\
\hline $\begin{array}{l}\text { 3. The Greek TFs will be produced with tasty raw materials in the post } \\
\text { COVID-19 era }\end{array}$ & 0.2 & 1.5 & 19.3 & 57.2 & 21.9 \\
\hline $\begin{array}{l}\text { 4. I am confident that the food technologies of the Greek TFs will result in tasty } \\
\text { foods in the post COVID-19 era }\end{array}$ & 0.2 & 1.5 & 21.2 & 56.0 & 21.2 \\
\hline $\begin{array}{l}\text { 5. I will be satisfied with how in the post COVID-19 era the food technologies of } \\
\text { the Greek TFs will result in tasty foods }\end{array}$ & 0.2 & 1.5 & 22.1 & 55.8 & 20.4 \\
\hline
\end{tabular}


The results of the chi-square test, presented in Table 10, showed that there were significant differences between the perceptions for TFs' taste in terms of:

1. Confidence in the taste of the Greek TFs: only between the level of education $\left(\mathrm{x}^{2}=185.729, p=0.000\right)$

2. Satisfaction with the taste of the Greek TFs: only between the level of education $\left(x^{2}=41.300, p=0.000\right)$.

3. Taste of the raw materials used: only between the level of education $\left(x^{2}=193.799\right.$, $p=0.000)$.

4. Confidence with the technologies used: between gender $\left(x^{2}=10.439, p=0.034\right)$ and level of education $\left(x^{2}=182.639, p=0.000\right)$.

5. Satisfaction with the technologies used: between the level of education $\left(x^{2}=183.483\right.$, $p=0.000)$, job situation $\left(x^{2}=15.619, p=0.048\right)$ and residency $\left(x^{2}=35.722, p=0.003\right)$.

Table 9 presents the participants' trust in the northwest (region of Epirus) Greek TFs and their raw materials in the post COVID-19 period. The results show that-by an average of 50\%-the participants "agree" that the Epirus' Greek TFs are worthy of being trusted (in terms of safety by $54.2 \%$ for the foods, and $53 \%$ for their raw materials; in terms of healthiness by $52.3 \%$ for the foods and $48.5 \%$ for the raw materials; in terms of sustainability by $50.9 \%$ for the foods and $49.5 \%$ for the raw materials; in terms of authenticity by $50.5 \%$ for the foods and $50.8 \%$ for the raw materials; and in terms of taste by $52.6 \%$ for the foods and $52.5 \%$ for the raw materials). A relatively high percentage-more than $20 \%$ - "strongly agree" about the safety (22.3\% for the foods and 22.2 for the raw materials), the healthiness (21.7\% for foods and $22.1 \%$ for the raw materials), the sustainability $(19.6 \%$ for the foods and $19.7 \%$ for the raw materials), the authenticity $(21.2 \%$ for the foods, $20.9 \%$ for the raw materials), and the taste (23.9\% for the foods, $23.6 \%$ for the raw materials) of Epirus' Greek TFs.

Table 9. Participants' trust in the northwest (Epirus' region) Greek TFs (scale from $1=$ strongly disagree to $5=$ strongly agree).

\begin{tabular}{|c|c|c|c|c|c|}
\hline \multirow{2}{*}{ Questions } & \multicolumn{5}{|c|}{ Answers According to Scale Points (\%) } \\
\hline & 1 & 2 & 3 & 4 & 5 \\
\hline 1. I am confident that the Epirus' Greek TFs will be safe in the post COVID-19 era & 0.2 & 1.8 & 21.4 & 54.2 & 22.3 \\
\hline $\begin{array}{l}\text { 2. The Epirus' Greek TFs will be produced with safe raw materials in the post } \\
\text { COVID-19 era }\end{array}$ & & 2.2 & 22.6 & 53.0 & 22.2 \\
\hline $\begin{array}{l}\text { 3. I am confident that the Epirus' Greek TFs will be healthy in the post } \\
\text { COVID-19 era }\end{array}$ & 0.2 & 1.9 & 23.9 & 52.3 & 21.7 \\
\hline $\begin{array}{l}\text { 4. The Epirus' Greek TFs will be produced with healthy raw materials in the post } \\
\text { COVID-19 era }\end{array}$ & 0.2 & 2.6 & 26.6 & 48.5 & 22.1 \\
\hline $\begin{array}{l}\text { 5. I am confident that the Epirus' Greek TFs will be produced in a sustainable way } \\
\text { in the post COVID-19 era (i.e., environmentally friendly, resource efficient, } \\
\text { ethically responsible) }\end{array}$ & 0.6 & 3.7 & 25.3 & 50.9 & 19.6 \\
\hline 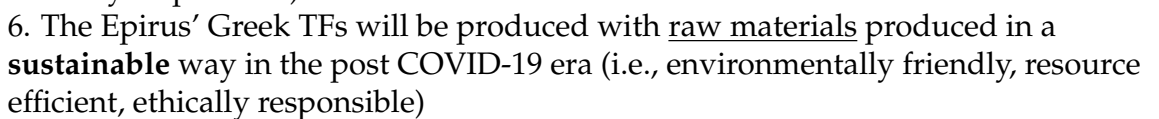 & 0.2 & 3.2 & 27.5 & 49.5 & 19.7 \\
\hline $\begin{array}{l}\text { 7. I am confident that the Epirus' Greek TFs will be authentic in the post COVID-19 } \\
\text { era (real, honest, genuine, not fake or artificial) }\end{array}$ & 0.0 & 2.6 & 25.8 & 50.5 & 21.2 \\
\hline $\begin{array}{l}\text { 8. The Epirus' Greek TFs will be produced with authentic raw materials in the post } \\
\text { COVID-19 era (real, honest, genuine, not fake or artificial) }\end{array}$ & 0.0 & 3.7 & 24.6 & 50.8 & 20.9 \\
\hline 9. I am confident that the Epirus' Greek TFs will be tasty in the post COVID-19 era & 0.2 & 1.3 & 22.0 & 52.6 & 23.9 \\
\hline $\begin{array}{l}\text { 10. The Epirus' Greek TFs will be produced with tasty raw materials in the post } \\
\text { COVID-19 era }\end{array}$ & 0.4 & 1.5 & 22.1 & 52.5 & 23.6 \\
\hline
\end{tabular}


The results of the chi-square test, presented in Table 10, showed that there were significant differences between the perceptions of the TFs' authenticity in terms of:

1. Confidence in the safety of the Epirus' TFs: only between residency $\left(x^{2}=36.757\right.$, $p=0.002)$.

2. Confidence in the safety of the raw materials for the Epirus' TFs: between gen$\operatorname{der}\left(x^{2}=8.235, p=0.045\right)$, level of education $\left(x^{2}=20.809, p=0.014\right)$ and residency $\left(x^{2}=28.965, p=0.004\right)$.

3. Confidence in the healthiness of the Epirus' TFs: between the level of education $\left(x^{2}=185.754, p=0.000\right)$, job situation $\left(x^{2}=32.460, p=0.000\right)$ and residency $\left(x^{2}=34.613\right.$, $p=0.004)$.

4. Confidence in the healthiness of the raw materials used for Epirus' TFs: between the level of education $\left(x^{2}=181.592, p=0.000\right)$, civil state $\left(x^{2}=17.306, p=0.027\right)$, job situation $\left(x^{2}=21.989, p=0.005\right)$ and residency $\left(x^{2}=35.744, p=0.003\right)$

5. Confidence in the sustainability of Epirus' TFs: between the level of education $\left(x^{2}=63.737, p=0.000\right)$, job situations $\left(x^{2}=30.166, p=0.000\right)$ and residency $\left(x^{2}=29.051\right.$, $p=0.024)$.

6. Confidence in the sustainability of the raw materials used for Epirus' TFs: only between civil state $\left(x^{2}=16.583, p=0.035\right)$ and residency $\left(x^{2}=29.856, p=0.019\right)$.

7. Confidence in the authenticity of Epirus' TFs: only between residency $\left(x^{2}=24.476\right.$, $p=0.018$ ).

8. Confidence in the authenticity of the raw materials used for Epirus' TFs: between civil state $\left(x^{2}=13.852, p=0.031\right)$, job situation $\left(x^{2}=17.627 p=0.007\right)$ and residency $\left(\mathrm{x}^{2}=29.950, p=0.003\right)$.

9. Confidence in the taste of Epirus' TFs: between gender $\left(x^{2}=13.235, p=0.010\right)$, level of education $\left(x^{2}=30.227, p=0.003\right)$ and residency $\left(x^{2}=38.560, p=0.001\right)$.

10. Confidence in the taste of the raw materials used for Epirus' TFs: only between residency $\left(x^{2}=31.282, p=0.012\right)$. 


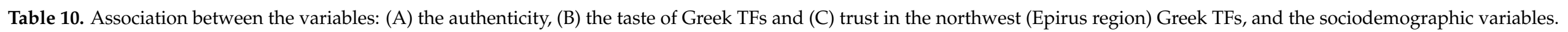

\begin{tabular}{|c|c|c|c|c|c|c|c|c|c|c|c|c|c|c|c|c|c|c|}
\hline & \multicolumn{3}{|c|}{ Gender } & \multicolumn{3}{|c|}{ Age } & \multicolumn{3}{|c|}{ Level of Education } & \multicolumn{3}{|c|}{ Civil State } & \multicolumn{3}{|c|}{ Job Situation } & \multicolumn{3}{|c|}{ Residency } \\
\hline & $\mathrm{x}^{2 *}$ & $p^{* *}$ & $\mathrm{~V}^{* * *}$ & $\mathrm{x}^{2}$ & $p$ & $\mathrm{v}$ & $\mathrm{x}^{2}$ & $p$ & $\mathrm{v}$ & $\mathrm{x}^{2}$ & $p$ & $\mathrm{v}$ & $\mathrm{x}^{2}$ & $p$ & $\mathrm{v}$ & $\mathrm{x}^{2}$ & $p$ & $\mathrm{v}$ \\
\hline \multicolumn{19}{|l|}{ A. Authenticity of the Greek TFs } \\
\hline $\begin{array}{l}\text { 1. I am confident that the Greek TFs will be authentic in the post } \\
\text { COVID-19 era (real, honest, genuine, not fake or artificial) }\end{array}$ & & & & & & & 94.729 & 0.000 & 0.241 & & & & 19.508 & 0.012 & 0.135 & & & \\
\hline $\begin{array}{l}\text { 3. The Greek TFs will be produced with authentic raw materials in the } \\
\text { post COVID-19 era (real, honest, genuine, not fake or artificial) } \\
\text { 4. I am confident that the food technologies of the Greek TFs will be }\end{array}$ & 10.551 & 0.032 & 0.140 & & & & & & & & & & & & & & & \\
\hline $\begin{array}{l}\text { authentic in the post COVID-19 era (real, honest, genuine, not fake } \\
\text { or artificial) } \\
\text { 5. I will be satisfied with the authenticity of the food technologies of the }\end{array}$ & 10.758 & 0.029 & 0.142 & 32.726 & 0.008 & 0.123 & & & & & & & 16.787 & 0.032 & 0.126 & & & \\
\hline \multicolumn{19}{|l|}{ B. Taste of the Greek TFs } \\
\hline 1. I am confident that the Greek TFs will be tasty in the post COVID-19 era & & & & & & & 185.729 & 0.000 & 0.338 & & & & & & & & & \\
\hline $\begin{array}{l}\text { 2. I will be satisfied with the taste of the Greek TFs in the post } \\
\text { COVID-19 era }\end{array}$ & & & & & & & 41.300 & 0.000 & 0.160 & & & & & & & & & \\
\hline $\begin{array}{l}\text { 3. The Greek TFs will be produced with tasty raw materials in the post } \\
\text { COVID-19 era }\end{array}$ & & & & & & & 193.799 & 0.000 & 0.347 & & & & & & & & & \\
\hline $\begin{array}{l}\text { 4. I am confident that the food technologies of the Greek TFs will result in } \\
\text { tasty foods in the post COVID-19 era }\end{array}$ & 10.439 & 0.034 & 0.139 & & & & 182.639 & 0.000 & 0.335 & & & & & & & & & \\
\hline $\begin{array}{l}\text { 5. I will be satisfied with how in the post COVID-19 era } \\
\text { the food technologies of the Greek TFs will result in tasty foods }\end{array}$ & & & & & & & 183.483 & 0.000 & 0.337 & & & & 15.619 & 0.048 & 0.121 & 35.722 & 0.003 & 0.129 \\
\hline \multicolumn{19}{|l|}{ C. Trust in the Northwest (Epirus' region) Greek TFs } \\
\hline $\begin{array}{l}\text { 1. I am confident that the Epirus' Greek TFs will be safe in the post } \\
\text { COVID-19 era }\end{array}$ & & & & & & & & & & & & & & & & 36.757 & 0.002 & 0.131 \\
\hline $\begin{array}{l}\text { 2. The Epirus' Greek TFs will be produced with safe raw materials in the } \\
\text { post COVID-19 era }\end{array}$ & 8.235 & 0.041 & 0.123 & & & & 20.809 & 0.014 & 0.113 & & & & & & & 28.965 & 0.004 & 0.134 \\
\hline $\begin{array}{l}\text { 3. I am confident that the Epirus' Greek TFs will be healthy in the post } \\
\text { COVID-19 era }\end{array}$ & & & & & & & 185.754 & 0.000 & 0.340 & & & & 32.460 & 0.000 & 0.175 & 34.613 & 0.004 & 0.127 \\
\hline $\begin{array}{l}\text { 4. The Epirus' Greek TFs will be produced with healthy raw materials in } \\
\text { the post COVID-19 era } \\
5 \text {. I am confident that the Epirus' Greek TFs will be produced in a }\end{array}$ & & & & & & & 181.592 & 0.000 & 0.336 & 17.306 & 0.027 & 0.127 & 21.989 & 0.005 & 0.144 & 35.744 & 0.003 & 0.129 \\
\hline $\begin{array}{l}\text { sustainable way in the post COVID-19 era (i.e., environmentally friendly, } \\
\text { resource efficient, ethically responsible) } \\
6 \text { The Epirus' Greek TFs will be produced with raw materials produced in }\end{array}$ & & & & & & & 63.737 & 0.000 & 0.198 & & & & 30.166 & 0.000 & 0.168 & 29.051 & 0.024 & 0.116 \\
\hline $\begin{array}{l}\text { a sustainable way in the post COVID-19 era (i.e., environmentally friendly, } \\
\text { resource efficient, ethically responsible) }\end{array}$ & & & & & & & & & & 16.583 & 0.035 & 0.124 & & & & 29.856 & 0.019 & 0.118 \\
\hline $\begin{array}{l}\text { 7. I m confident that the Epirus' Greek TFs will be authentic in the post } \\
\text { COVID-19 era (real, honest, genuine, not fake or artificial) }\end{array}$ & & & & & & & & & & & & & & & & 24.476 & 0.018 & 0.123 \\
\hline $\begin{array}{l}\text { 8. The Epirus' 'Greek TFs will be produced with authentic raw materials in } \\
\text { the post COVID-19 era (real, honest, genuine, not fake or artificial) }\end{array}$ & & & & & & & & & & 13.852 & 0.031 & 0.113 & 17.627 & 0.007 & 0.128 & 29.950 & 0.003 & 0.136 \\
\hline $\begin{array}{l}\text { 9. I am confident that the Epirus' Greek TFs will be tasty in the post } \\
\text { COVID-19 era }\end{array}$ & 13.235 & 0.010 & 0.157 & & & & 30.227 & 0.003 & 0.137 & & & & & & & 38.560 & 0.001 & 0.134 \\
\hline $\begin{array}{l}\text { 10. The Epirus' Greek will be produced with tasty raw materials in the } \\
\text { post COVID-19 era }\end{array}$ & & & & & & & & & & & & & & & & 31.282 & 0.012 & 0.120 \\
\hline
\end{tabular}




\section{Discussion}

In this research, the consumer's trust regarding TFs, specifically Greek TFs, following the COVID-19 pandemic was studied for the first time. The objective was to predict the future of TFs as the foods of choice in the new global economic and social era, which is already underway. Greece was chosen for the study because it is a Mediterranean, EU country with increased production and use of TFs. The Greek region of Epirus, a mountainous, environmentally intact region with increased TFs, was also used in the study in order to compare the results with the rest of the Greek TFs. The sociodemographic characteristics of the participants of the survey had suitable distribution between the different categories, similar to other recent reports [53]. They were from all different parts of Greece in order to ensure geographical distribution.

The participants in this study showed a high positive perception of all of the parameters studied regarding the safety of TFs, their raw materials and their production technologies used (more than 75\%), as shown in Table 3. The results of the chi-square test indicated that there were significant differences regarding safety between: (a) "gender" regarding raw materials, with a weak association $(\mathrm{V}=0.164)$; (b) "age" regarding confidence and satisfaction with TFs and the used technologies used, with a weak association $(\mathrm{V}=0.122 / 0.124 / 0.118 / 0.112)$; (c) "level of education" regarding confidence and satisfaction in/with TFs, the used technologies, and the raw materials used, with a weak to moderate association $(\mathrm{V}=0.215 / 0.254 / 0.251 / 0.255 / 0.473)$; $(\mathrm{d})$ "civil state" regarding the satisfaction with TFs, with a weak association $(\mathrm{V}=0.130)$; (e) "job situation" regarding the satisfaction with TFs, and confidence and satisfaction with the technologies used, with a weak association $(\mathrm{V}=0.124 / 0.150 / 0.156)$; $(\mathrm{f})$ "residency" regarding raw materials and the satisfaction with the used technologies, with a weak association $(\mathrm{V}=0.125 / 0.117)$. The safety of foods regarding consumers' perceptions has been studied thoroughly in the previous decade as one of the major parameters for the choice of food [33,38]. The results of a recent study, conducted during the pandemic period, indicate that society came to a consensus on trust in the safety of food [54]. The observed differences in outlet and food choices can be explained by income, settlement type, and age, in a pattern similar to our results presented here.

Overall, the participants consider Greek TFs to be healthy foods in the post COVID19 period. However, the perceived positive result for health, more than $72 \%$ (Table 4) was slightly lower than the perceived result for safety. The results of the chi-square test indicated that there were significant differences regarding healthiness between: (a) "level of education" regarding confidence and satisfaction in the TFs, the used technologies, and the raw materials, with a weak to moderate association $(V=0.336 / 0.196 / 0.252 / 0.117 / 0.170)$; (b) "job situation" regarding confidence and satisfaction with TFs, with a weak association $(\mathrm{V}=0.157 / 0.126)$. Because of the pandemic, the health parameter as a main reason for food selection was studied thoroughly recently. A study with Romanian participants found that, with aging, there is an increasing concern regarding the practice of a healthy diet [55], with a higher education level being significantly associated with healthier choices. The adoption of healthier food habits for grocery shopping varied significantly with the gender, age and household income of the respondents in another study [56]. Our results, in terms of health issues regarding TFs, agree with the findings of both reports. Other recent studies found environmental factors, together with health, to be the determinants of choices for Italian consumers [57], and that there is a shift towards healthier diets for Russian adults [58]. These findings were also verified by our results in the case of TFs.

The positive results regarding participants' perceptions of the sustainability of the Greek TFs, as shown in Table 5, are slightly lower than the previous two parameters, with an overall positive perception of no more than $65 \%$. The results of the chi-square test indicated that there were significant differences regarding sustainability between: (a) "age" regarding the satisfaction with the used technologies, with a weak association $(\mathrm{V}=0.122)$; (b) "level of education" regarding satisfaction with TFs, and the confidence in the used technologies and the raw materials, with a weak association ( $\mathrm{V}=0.124 / 0.138 / 0.133)$; (c) "civil 
state" regarding confidence with the TFs, and satisfaction with the used technologies and the raw materials, with a weak association ( $\mathrm{V}=0.143 / 0.147 / 0.134)$; (d) "job situation" regarding satisfaction with the TFs, and confidence and satisfaction with the technologies used and the raw materials, with a weak association ( $\mathrm{V}=0.130 / 0.162 / 0.126 / 0.144)$. A previous study indicated that attempts at stimulating sustainable consumption might be most effective when differences across consumer segments are taken into account [59]. Motivational imbalance has significant moderating effects, such that consumers who experience motivation imbalance showed consistently weaker intentions to consume sustainable foods than consumers who experience motivation balance [60]. Considering organic food as the mechanism to obtain a more sustainable food production and consumption system, the theoretical implications highlight the importance of the evaluation of more sustainable consumption forms in line with consumer profile particularities [61]. In accordance with these findings, our results indicate that TFs in the perception of the consumer have sustainable characteristics of preference, such as organic foods.

Comparable results with the sustainability parameter were recorded for the authenticity parameter, as shown in Table 7 above, with an overall positive feedback of no more than $64 \%$. The results of the chi-square test indicated that there were significant differences regarding authenticity between: (a) "gender" regarding satisfaction with the TFs, and confidence in the used technologies and the raw materials, with a weak association (V=0.134/0.142/0.140); (b) "age" regarding satisfaction with the TFs and confidence in the used technologies, with a weak association ( $\mathrm{V}=0.112 / 0.123)$; (c) "level of education" regarding confidence and satisfaction with the TFs, and satisfaction with the used technologies, with a weak to moderate association $(\mathrm{V}=0.241 / 0.206 / 0.189)$; (d) "job situation" regarding confidence in the TFs and the technologies used, with a weak association $(\mathrm{V}=0.135 / 0.126)$. A recent study indicated that organic certificates, traditional and homemade production practices, origin certificates, and information about products' origin country and raw material production region are significant quality cues enabling consumers to judge food authenticity [62]. These are all characteristics that the Greek TFs have as well, which explains our positive results in this parameter in accordance with the exiting literature.

When it comes to the taste of Greek TFs, as shown in Table 8, the positive results recorded were as high as the safety parameter, with a minimum positive perception of $75 \%$. The results of the chi-square test indicated that there were significant differences regarding taste between: (a) "gender" regarding raw materials, with a weak association (V = 0.139); (b) "level of education" regarding confidence and satisfaction with the TFs, and with the used technologies and the raw materials, with a weak to moderate association (V = 0.338/0.160/0.335/0.337/0.347); (c) “job situation" regarding satisfaction with the technologies used, with a weak association $(\mathrm{V}=0.121$; and $(\mathrm{d})$ "residency" regarding satisfaction with the used technologies, with a weak association $(\mathrm{V}=0.129)$. The literature indicates that even owners of strong food brands cannot trust the ability of their brands to boost a consumer's taste experience if there is no correspondence between his or her central values and the brand symbolism [63]. In another study, parental consumption attitudes were not associated with children's fat, sweet and umami taste preferences [64]. Unfavorable parental consumer attitudes were associated with a lower parental education across Europe. Our findings support the above-mentioned literature for the importance of taste for food selection.

The participants' trust in Epirus' Greek TFs and their raw materials used, as shown in Table 9, compared with the trust in all of the Greek TFs, followed a similar pattern for most of the five parameters tested. The participants' perceptions of the taste of TFs was slightly lower for the Epirus' TFs. The results of the chi-square test indicated that there were significant differences regarding trust for Epirus' TFs between: (a) "gender" regarding the safety of the raw materials and the taste of TFs, with a weak association $(\mathrm{V}=0.123 / 0.157)$; (b) "level of education" regarding the safety and healthiness of the raw materials, healthiness, sustainability and taste of the TFs, with a weak to 
moderate association $(\mathrm{V}=0.113 / 0.336 / 0.340 / 0.198 / 0.137) ;(\mathrm{c})$ "civil state" regarding the healthiness, sustainability and authenticity of the raw materials, with a weak association (V = 0.127/0.124/0.113); (d) "job situation" regarding the healthiness and sustainability of TFs and healthiness, authenticity of raw materials with a weak association (V=0.175/0.168/0.144/0.128); (e) "residency" regarding the safety, healthiness, sustainability, authenticity and taste of TFs, and the raw materials used, with a weak association $(\mathrm{V}=0.131 / 0.127 / 0.116 / 0.123 / 0.134 / 0.134 / 0.129 / 0.118 / 0.136 / 0.120$ respectively). Recent results suggest that COVID-19 psychological pressure was associated with an impulsive approach to buying food [65]. Consequently, food-purchasing behavior is expected to revert to pre-COVID-19 habits when the emergency in over [65]. However, our findings in this, and a recently published study [6], indicate that the increased trust, attitudes and perceptions towards TFs will be long lasting in the new post COVID-19 economy.

\section{Conclusions}

This research work explored consumers' trust in the Greek TFs at the beginning of an unprecedented and unpredictable social and economic period such as the post COVID-19 era. The present contribution applied the five main parameters of food trust in the TFs in the Greek consumers' mind in order to identify the variables that predicted the preference for the purchase of TFs in this new, unknown period which is changing our lives, our habits and our selections completely. To this purpose, an online survey was used to a sample 548 participants, with gender, age, education, civil state, employment and permanent residency across Greece balanced at the time of the survey conducted recently (May-June 2021). With the drastic change of consumers' behavior for all goods and services, due to the effect of the present pandemic, consumers will change their preference for foods too, in a way which is not clear yet. It is expected that people will spend less for food, in a more selected, personalized way, away from the old massive, unquestionable way. Our results show that the customers of this study appreciate-in order of importance-the safety, the taste, the healthiness, the sustainability, and the authenticity that the TFs, their raw materials, and the used technologies offer in this post COVID-9 era, making them the future foods of choice. Customers are confident and satisfied with the five characteristics associated with TFs. They evaluate the taste equally with the safety, then the healthiness, and last the sustainability and the authenticity of the TFs. They also evaluate, in the same way, the five parameters in all three items, namely the TFs themselves, their raw materials, and the used technologies for their production.

In order to understand whether or not consumers' evaluation of the trust in Greek TFs is driven by local characteristics, a regional TF group of products, namely the northwest Greek (the region of Epirus) TFs were used at the end of the same survey with the same participants. The results showed that customers evaluated in a similar manner Epirus' TFs, raw materials and technologies for the parameters of trust, except the taste, which was considered inferior compared to the taste of the overall Greek TFs.

More women, more people with university degrees, and more people with jobs took part in the survey, and this is a limitation of the study, considering the relatively limited number of responses obtained. Another limitation of the study was the use of the Greek TFs, as compared with the TFs from other countries. However, this study is the first approach to understand the trust in TFs for purchase and consumption in the new period after the pandemic crisis, highlighting which aspects are more relevant for the consumption of these types of products from the consumers' point of view.

The findings of the study are promising for the role of the TFs as the foods of choice, and consequently as the major local economic drivers, in the new post COVID-19 period. However further studies are needed in order to investigate further the parameters of trust in the TFs, the long lasting effects and the adaptation behaviors for the "new normality". The findings will contribute further to the ultimate goal, which is to integrate TFs into the daily consumption of selected consumers in different parts of the world, including Greece. Further studies should expand in two different directions: studying the TFs of 
other countries, primarily in the EU, either themselves or in comparison, and studying the concept of trust in depth, looking at other parameters as well for Greek TFs, making them more accessible to consumers.

Author Contributions: Conceptualization, supervision, methodology, D.S.; writing—original draft preparation, D.S. and I.S.K.; investigation, A.V.; review and editing, D.S. and R.P.F.G. All authors have read and agreed to the published version of the manuscript.

Funding: This research received no external funding.

Institutional Review Board Statement: Not applicable.

Informed Consent Statement: Not applicable.

Data Availability Statement: Not applicable.

Conflicts of Interest: The authors declare no conflict of interest.

\section{References}

1. Kotler, P. The Consumer in the Age of Coronavirus. J. Creat. Value 2020, 6, 12-15. [CrossRef]

2. Chenarides, L.; Grebitus, C.; Lusk, J.L.; Printezis, I. Food consumption behavior during the COVID-19 pandemic. Agribusiness 2021, 37, 44-81. [CrossRef] [PubMed]

3. Hansmann, R.; Baur, I.; Binder, C.R. Increasing organic food consumption: An integrating model of drivers and barriers. J. Clean. Prod. 2020, 275, 123058. [CrossRef]

4. Eftimov, T.; Popovski, G.; Petković, M.; Seljak, B.K.; Kocev, D. COVID-19 pandemic changes the food consumption patterns. Trends Food Sci. Technol. 2020, 104, 268-272. [CrossRef] [PubMed]

5. Hirvonen, K.; de Brauw, A.; Abate, G.T. Food Consumption and Food Security during the COVID-19 Pandemic in Addis Ababa. Am. J. Agric. Econ. 2021, 103, 772-789. [CrossRef]

6. Skalkos, D.; Kosma, I.S.; Chasioti, E.; Skendi, A.; Papageorgiou, M.; Guiné, R.P.F. Consumers' Attitude and Perception toward Traditional Foods of Northwest Greece during the COVID-19 Pandemic. Appl. Sci. 2021, 11, 4080. [CrossRef]

7. Almli, V.L. Consumer Acceptance of Innovations in Traditional Food. Attitudes, Expectations and Perception. Ph.D. Thesis, Norwegian University of Life Sciences, Ås, Norway, 2012.

8. Trichopoulou, A.; Soukara, S.; Vasilopoulou, E. Traditional foods: A science and society perspective. Trends Food Sci. Technol. 2007, 18, 420-427. [CrossRef]

9. Vanhonacker, F.; Kühne, B.; Gellynck, X.; Guerrero, L.; Hersleth, M.; Verbeke, W. Innovations in traditional foods: Impact on perceived traditional character and consumer acceptance. Food Res. Int. 2013, 54, 1828-1835. [CrossRef]

10. Kühne, B.; Vanhonacker, F.; Gellynck, X.; Verbeke, W. Innovation in traditional food products in Europe: Do sector innovation activities match consumers' acceptance? Food Qual. Prefer. 2010, 21, 629-638. [CrossRef]

11. Skalkos, D. Traditional Foods in Europe: Perceptions \& Prospects in the New Business Era. Mod. Concepts Dev. Agron. 2021, 8, 787-789. [CrossRef]

12. Certificates of specific character for agricultural products and food ststus. Off. J. Eur. Union 1992, 9-14. Available online: https:/ / op.europa.eu/en/publication-detail/-/publication/a109261e-f10f-4710-a609-5d4a0a282252/language-en (accessed on 3 September 2021).

13. Agricultural products and food stuffs as traditional specialities quaranteed. Off. J. Eur. Union 2006, 1-11. Available online: https:/ / eur-lex.europa.eu/legal-content/EN/TXT/?uri=celex\%3A32006R0509 (accessed on 3 September 2021).

14. Protection of geographical indications and designations of origin for agricultutral products and food stuffs. Off. J. Eur. Union 2006, 12-25. Available online: https:/ / eur-lex.europa.eu/legal-content/EN/TXT/?uri=CELEX\%3A32006R0510 (accessed on 3 September 2021).

15. Quality schemes for agricultural products and food stuffs. Off. J. Eur. Union 2012, 31-59. Available online: https: / / eur-lex.europa. eu/legal-content/EN/TXT/?uri=CELEX\%3A32012R1151 (accessed on 3 September 2021).

16. Greek Traditional products (PDO-PGI-TSG). Hellenic Ministry of Agricultural Development and Food. Available online: http://www.minagric.gr/index.php/el/for-farmer-2/2012-02-02-07-52-07 (accessed on 3 September 2021).

17. EU Geographical Indications Register. Available online: https:/ / ec.europa.eu/info/food-farming-fisheries/food-safety-andquality / certification/quality-labels/geographical-indications-register/ (accessed on 3 September 2021).

18. Palupi, S.; Abdillah, F. Local Cuisine as a Tourism Signature. In Delivering Tourism Intelligence; Emerald Publishing Limited: Bingley, UK, 2019; pp. 299-312.

19. Trichopoulou, A.; Vasilopoulou, E.; Georga, K.; Soukara, S.; Dilis, V. Traditional foods: Why and how to sustain them. Trends Food Sci. Technol. 2006, 17, 498-504. [CrossRef]

20. Trichopoulou, A.; Naska, A.; Orfanos, P.; Trichopoulos, D. Mediterranean diet in relation to body mass index and waist-to-hip ratio: The Greek European Prospective Investigation into Cancer and Nutrition Study. Am. J. Clin. Nutr. 2005, 82, 935-940. [CrossRef] 
21. Trichopoulou, A.; Costacou, T.; Bamia, C.; Trichopoulos, D. Adherence to a Mediterranean Diet and Survival in a Greek Population. N. Engl. J. Med. 2003, 348, 2599-2608. [CrossRef]

22. Trichopoulou, A.; Bamia, C.; Trichopoulos, D. Mediterranean diet and survival among patients with coronary heart disease in Greece. Arch. Intern. Med. 2005, 165, 929-935. [CrossRef]

23. Vasilopoulou, E.; Georga, K.; Joergensen, M.B.; Naska, A.; Trichopoulou, A. The antioxidant properties of Greek foods and the flavonoid content of the Mediterranean menu. Curr. Med. Chem. Immunol. Endocr. Metab. Agents 2005, 5, 33-45. [CrossRef]

24. Trichopoulou, A.; Vasilopoulou, E.; Hollman, P.; Chamalides, C.; Foufa, E.; Kaloudis, T.; Kromhout, D.; Miskaki, P.; Petrochilou, I.; Poulima, E.; et al. Nutritional composition and flavonoid content of edible wild greens and green pies: A potential rich source of antioxidant nutrients in the Mediterranean diet. Food Chem. 2000, 70, 319-323. [CrossRef]

25. Trichopoulou, A.; Vasilopoulou, E.; Georga, K. Macro- and micronutrients in a traditional Greek menu. Forum Nutr. 2005, 57, 135-146.

26. Hobbs, J.E.; Goddard, E. Consumers and trust. Food Policy 2015, 52, 71-74. [CrossRef]

27. Kaiser, M.; Algers, A. Trust in Food and Trust in Science. Food Ethics 2017, 1, 93-95. [CrossRef]

28. Sapp, S.G.; Arnot, C.; Fallon, J.; Fleck, T.; Soorholtz, D.; Sutton-Vermeulen, M.; Wilson, J.J.H. Consumer Trust in the U.S. Food System: An Examination of the Recreancy Theorem. Rural Sociol. 2010, 74, 525-545. [CrossRef]

29. Ross, V.L.; Fielding, K.S.; Louis, W.R. Social trust, risk perceptions and public acceptance of recycled water: Testing a socialpsychological model. J. Environ. Manag. 2014, 137, 61-68. [CrossRef] [PubMed]

30. Siegrist, M.; Cousin, M.E.; Kastenholz, H.; Wiek, A. Public acceptance of nanotechnology foods and food packaging: The influence of affect and trust. Appetite 2007, 49, 459-466. [CrossRef] [PubMed]

31. Lobb, A.E.; Mazzocchi, M.; Traill, W.B. Modelling risk perception and trust in food safety information within the theory of planned behaviour. Food Qual. Prefer. 2007, 18, 384-395. [CrossRef]

32. Janssen, M.; Hamm, U. Governmental and private certification labels for organic food: Consumer attitudes and preferences in Germany. Food Policy 2014, 49, 437-448. [CrossRef]

33. De Jonge, J.; van Trijp, H.; Goddard, E.; Frewer, L. Consumer confidence in the safety of food in Canada and the Netherlands: The validation of a generic framework. Food Qual. Prefer. 2008, 19, 439-451. [CrossRef]

34. Tilman, D.; Clark, M. Global diets link environmental sustainability and human health. Nature 2014, 515, 518-522. [CrossRef]

35. Willett, W.; Rockström, J.; Loken, B.; Springmann, M.; Lang, T.; Vermeulen, S.; Garnett, T.; Tilman, D.; DeClerck, F.; Wood, A.; et al. Food in the Anthropocene: The EAT-Lancet Commission on healthy diets from sustainable food systems. Lancet 2019, 393, 447-492. [CrossRef]

36. Afshin, A.; Sur, P.J.; Fay, K.A.; Cornaby, L.; Ferrara, G.; Salama, J.S.; Mullany, E.C.; Abate, K.H.; Abbafati, C.; Abebe, Z.; et al. Health effects of dietary risks in 195 countries, 1990-2017: A systematic analysis for the Global Burden of Disease Study 2017. Lancet 2019, 393, 1958-1972. [CrossRef]

37. Macready, A.L.; Hieke, S.; Klimczuk-Kochańska, M.; Szumiał, S.; Vranken, L.; Grunert, K.G. Consumer trust in the food value chain and its impact on consumer confidence: A model for assessing consumer trust and evidence from a 5-country study in Europe. Food Policy 2020, 92, 101880. [CrossRef]

38. De Jonge, J.; Van Trijp, H.; Jan Renes, R.; Frewer, L. Understanding consumer confidence in the safety of food: Its two-dimensional structure and determinants. Risk Anal. 2007, 27, 729-740. [CrossRef]

39. Gefen, D.; Straub, D.W. Consumer trust in B2C e-Commerce and the importance of social presence: Experiments in e-Products and e-Services. Omega 2004, 32, 407-424. [CrossRef]

40. Poortinga, W.; Pidgeon, N.F. Exploring the dimensionality of trust in risk regulation. Risk Anal. 2003, 23, 961-972. [CrossRef]

41. Zhang, A.; Mankad, A.; Ariyawardana, A. Establishing confidence in food safety: Is traceability a solution in consumers' eyes? J. Verbrauch. Lebensm. 2020, 15, 99-107. [CrossRef]

42. Fernández-Zarza, M.; Amaya-Corchuelo, S.; Belletti, G.; Aguilar-Criado, E. Trust and food quality in the valorisation of geographical indication initiatives. Sustainability 2021, 13, 3168. [CrossRef]

43. Guiné, R.; Ferrão, A.C.; Ferreira, M.; Correia, P.; Cardoso, A.P.; Duarte, J.; Rumbak, I.; Shehata, A.M.; Vittadini, E.; Papageorgiou, M. The motivations that define eating patterns in some Mediterranean countries. Nutr. Food Sci. 2019, 49, 1126-1141. [CrossRef]

44. Palmieri, N.; Suardi, A.; Pari, L. Italian consumers' willingness to pay for eucalyptus firewood. Sustainability 2020, $12,2629$. [CrossRef]

45. Palmieri, N.; Perito, M.A.; Macrì, M.C.; Lupi, C. Exploring consumers' willingness to eat insects in Italy. Br. Food J. 2019, 121, 2937-2950. [CrossRef]

46. Palmieri, N.; Perito, M.A.; Lupi, C. Consumer acceptance of cultured meat: Some hints from Italy. Br. Food J. 2020, 123, 109-123. [CrossRef]

47. Palmieri, N.; Perito, M.A. Consumers' willingness to consume sustainable and local wine in Italy. Ital. J. Food Sci. 2020, 32, 222-233. [CrossRef]

48. De Leeuw, A.; Valois, P.; Ajzen, I.; Schmidt, P. Using the theory of planned behavior to identify key beliefs underlying proenvironmental behavior in high-school students: Implications for educational interventions. J. Environ. Psychol. 2015, 42, 128-138. [CrossRef]

49. Pappalardo, G.; Lusk, J.L. The role of beliefs in purchasing process of functional foods. Food Qual. Prefer. 2016, 53, 151-158. [CrossRef] 
50. Chinnici, G.; D'Amico, M.; Pecorino, B. A multivariate statistical analysis on the consumers of organic products. Br. Food J. 2002, 104, 187-199. [CrossRef]

51. Giampietri, E.; Verneau, F.; Del Giudice, T.; Carfora, V.; Finco, A. A Theory of Planned behaviour perspective for investigating the role of trust in consumer purchasing decision related to short food supply chains. Food Qual. Prefer. 2018, 64, 160-166. [CrossRef]

52. Likert, R. A technique for the measurement of attitudes. Arch. Psychol. 1932, 140, 44-53.

53. Petrescu-Mag, R.M.; Vermeir, I.; Petrescu, D.C.; Crista, F.L.; Banatean-Dunea, I. Traditional foods at the click of a button: The preference for the online purchase of romanian traditional foods during the COVID-19 pandemic. Sustainability 2020, 12, 9956. [CrossRef]

54. Skripnuk, D.F.; Davydenko, V.A.; Romashkina, G.F.; Khuziakhmetov, R.R. Consumer Trust in Quality and Safety of Food Products in Western Siberia. Agronomy 2021, 11, 257. [CrossRef]

55. Bacârea, A.; Bacârea, V.C.; Cînpeanu, C.; Teodorescu, C.; Seni, A.G.; Guiné, R.P.F.; Tarcea, M. Demographic, anthropometric and food behavior data towards healthy eating in romania. Foods 2021, 10, 487. [CrossRef] [PubMed]

56. Shamim, K.; Ahmad, S.; Alam, M.A. COVID-19 health safety practices: Influence on grocery shopping behavior. J. Public Aff. 2021, e2624. [CrossRef]

57. Wongprawmas, R.; Mora, C.; Pellegrini, N.; Guiné, R.P.F.; Carini, E.; Sogari, G.; Vittadini, E. Food choice determinants and perceptions of a healthy diet among Italian consumers. Foods 2021, 10, 318. [CrossRef] [PubMed]

58. Ben Hassen, T.; El Bilali, H.; Allahyari, M.S.; Berjan, S.; Fotina, O. Food purchase and eating behavior during the COVID-19 pandemic: A cross-sectional survey of Russian adults. Appetite 2021, 165, 105309. [CrossRef] [PubMed]

59. Rodríguez-Pérez, C.; Molina-Montes, E.; Verardo, V.; Artacho, R.; García-Villanova, B.; Guerra-Hernández, E.J.; Ruíz-López, M.D. Changes in dietary behaviours during the COVID-19 outbreak confinement in the Spanish COVIDiet study. Nutrients 2020, 12, 1730. [CrossRef]

60. Elhoushy, S. Consumers' sustainable food choices: Antecedents and motivational imbalance. Int. J. Hosp. Manag. 2020, 89, 102554. [CrossRef]

61. Feil, A.A.; da Silva Cyrne, C.C.; Sindelar, F.C.W.; Barden, J.E.; Dalmoro, M. Profiles of sustainable food consumption: Consumer behavior toward organic food in southern region of Brazil. J. Clean. Prod. 2020, 258, 120690. [CrossRef]

62. Chousou, C.; Mattas, K. Assessing consumer attitudes and perceptions towards food authenticity. Br. Food J. 2019, $123,1947-1961$. [CrossRef]

63. Paasovaara, R.; Luomala, H.T.; Pohjanheimo, T.; Sandell, M. Understanding consumers' brand-induced food taste perception: A comparison of "brand familiarity" - And "consumer value-brand symbolism (in)congruity" -Accounts. J. Consum. Behav. 2012, 11, 11-20. [CrossRef]

64. Jilani, H.S.; Pohlabeln, H.; Buchecker, K.; Gwozdz, W.; De Henauw, S.; Eiben, G.; Molnar, D.; Moreno, L.A.; Pala, V.; Reisch, L.; et al. Association between parental consumer attitudes with their children's sensory taste preferences as well as their food choice. PLoS ONE 2018, 13, e0200413. [CrossRef]

65. Russo, C.; Simeone, M.; Demartini, E.; Marescotti, M.E.; Gaviglio, A. Psychological pressure and changes in food consumption: The effect of COVID-19 crisis. Heliyon 2021, 7, e06607. [CrossRef] [PubMed] 